\title{
EVALUASI SISTEM INFORMASI AKUNTANSI PENJUALAN KREDIT
}

\section{EVALUATION OF ACCOUNTING SALES ACCOUNTING INFORMATION SYSTEMS}

\author{
Ayu Aprianty \\ Universitas Muhammadiyah Jember \\ ayuapriyanti24@gmail.com
}

\begin{abstract}
Sales accounting information system is a system that is useful as a control tool for the implementation of a company's transactions. This research was conducted with the aim to find out how the credit sales information system in PD. Sinar Mas Hakasima Branch Jember, to find out how-not-the credit sales accounting information system has been done well. The analytical method used in this study is descriptive qualitative. Data collection techniques, interview techniques, observation / observation and documentation. The data used are primary data consisting of the results of direct interviews regarding credit sales accounting information systems. Based on the results of the analysis conducted by researchers, it can be seen that the credit sales accounting information system applied by PD. The Masasasima Branch of Jember Branch in processing credit sales transactions is good, the company has a good and adequate information system.
\end{abstract}

Keywords: Accounting Information Systems, Credit Sales, Accounting Information System Elements

\begin{abstract}
ABSTRAK
Sistem informasi akuntansi penjualan adalah sistem yang berguna sebagai alat kontrol untuk pelaksanaan transaksi perusahaan. Penelitian ini dilakukan dengan tujuan untuk mengetahui bagaimana sistem informasi penjualan kredit pada PD. Sinar Mas Hakasima Cabang Jember, untuk mengetahui bagaimana-bukan-sistem informasi akuntansi penjualan kredit telah dilakukan dengan baik. Metode analisis yang digunakan dalam penelitian ini adalah deskriptif kualitatif. Teknik pengumpulan data, teknik wawancara, observasi / observasi dan dokumentasi. Data yang digunakan adalah data primer yang terdiri dari hasil wawancara langsung mengenai sistem informasi akuntansi penjualan kredit. Berdasarkan hasil analisis yang dilakukan oleh peneliti, dapat diketahui bahwa sistem informasi akuntansi penjualan kredit diterapkan oleh PD. Cabang Masasasima Cabang Jember dalam memproses transaksi penjualan kredit yang baik, perusahaan memiliki sistem informasi yang baik dan memadai.
\end{abstract}

Kata Kunci: Sistem Informasi Akuntansi, Penjualan Kredit, Elemen Sistem Informasi Akuntansi 


\section{PENDAHULUAN}

Perkembangan

teknologi

informasi saat ini telah berkembang pesat, dimana hampir semua bidang aplikasi bisnis telah memakai dan mengembangkan sistem informasi dengan sedemikian rupa sehingga mampu memajukan dan mengembangkan usaha dengan sangat baik, (Dharma, 2010). Salah satu langkah yang dapat ditempuh perusahaan agar mampu bersaing dalam dunia bisnis adalah dengan mengimplementasikan sistem informasi akuntansi yang efektif. Dengan memiliki sistem informasi akuntansi maka perusahaan dapat memiliki keunggulan kompetitif strategis, karena sistem informasi akuntansi akan dapat menjamin keakuratan, kevalidan, dan ketepatwaktuan informasi yang dibutuhkan dalam proses pengambilan keputusan untuk perencanaan, pelaksanaan dan pengendalian.

Romney dan Steinbart (2014) mengatakan bahwa, sistem informasi akuntansi adalah proses identifikasi, pengumpulan, dan penyimpanan data serta proses pengembangan, pengukuran dan komunikasi informasi. Sistem informasi akuntansi terdiri dari organisasi formulir, catatan, dan laporan yang dikoordinasi sedemikian rupa untuk menyediakan informasi keuangan yang dibutuhkan oleh manajemen guna memudahkan pengelolaan perusahaan. Sistem ini menyiapkan informasi bagi manajemen dengan melaksanakan operasi - operasi tertentu atas semua sumber yang diterimanya dan juga mempengaruhi hubungan organisasi perusahaan dan lingkungan sekitarnya.

Sistem informasi akuntansi penjualan merupakan sistem yang berguna sebagai alat kontrol terhadap pelaksanaan suatu transaksi perusahaan, atau bisa juga berguna untuk mengetahui kemajuan yang diraih oleh perusahaan dalam jangka waktu yang telah ditetapkan sebelumnya. Dengan adanya sistem informasi akuntansi penjualan, perusahaan dapat memberikan pelayanan yang lebih baik bagi pelanggannya, dan dapat diharapkan loyalitas pelanggan dapat meningkat dan penjualan perusahaan juga akan meningkat. Sistem akuntansi penjualan yang baik merupakan sistem informasi yang dapat memberikan informasi yang tepat, cepat dan akurat tentang penjualan baik sekarang maupun yang akan datang. Prosedur penjualan dan pencatatan yang baik, benar, serta sesuai dengan kebutuhan perusahaan dapat dijalankan dengan adanya sebuah sistem yaitu sistem informasi akuntansi penjualan.

Kenaikan penjualan akan meningkatkan laba perusahaan, atau dengan kata lain besar kecilnya laba yang diperoleh perusahaan tergantung pada aktivitas penjualan. Penjualan sendiri dibagi menjadi dua yaitu penjualan tunai dan penjualan kredit. Penjualan kredit harus mendapatkan perhatian yang khusus, karena merupakan sumber penerimaan kas perusahaan yaitu melalui pelunasan piutang. Penjualan kredit dilakukan perusahaan dengan cara mengirimkan barang sesuai order yang diterima dari pembeli dan untuk jangka waktu tertentu perusahaan mempunyai tagihan kepada pembeli tersebut. Penjualan kredit lebih banyak diminati oleh para konsumen dibanding penjualan tunai karena transaksi pembayarannya dapat ditunda sesuai dengan kesepakatan, selain itu perusahaan juga mendapat keuntungan yang lebih besar dari adanya penjualan kredit dikarenakan harga yang akan dibayar pembeli secara kredit sedikit lebih mahal dibandingkan dengan membeli secara tunai. 
PD. Sinar Mas Hakasima merupakan sebuah perusahaan yang bergerak dalam bidang penjualan alatalat memasak dengan skala pemasaran yang cukup luas. Mengingat dalam pasar alat-alat memasak banyak pelaku pasar lainnya, maka PD. Sinar Mas Hakasima menghadapi persaingan yang cukup tinggi. Agar dapat bersaing, maka salah satu langkah yang dilakukan oleh perusahaan adalah dengan mengimplementasikan sistem informasi akuntansi penjualan.

Penjualan pada PD. Sinar Mas Hakasima Cabang Jember dilakukan secara kredit, prosedur yang dilakukan penjualan kredit meliputi prosedur pemesanan barang, persetujuan kredit, prosedur pengiriman barang, prosedur penagihan, dan prosedur pencatatan piutang. Dengan pelaksanaan kegiatan penjualan dan sistem informasi akuntansi penjualan yang baik maka diharapkan dapat diketahui perkembangan perusahaan dari waktu ke waktu.

Penjualan alat-alat memasak melibatkan perputaran keuangan yang sangat besar dan apabila tidak dikelola dengan baik dapat mempengaruhi kelangsungan hidup perusahaan. Masalah keuangan yang dihadapi dalam bidang penjualan alat-alat memasak dapat merupakan masalah pokok (penentu) didalam perencanaan strategi penjualan, sering adanya kesalahan input data yang mengakibatkan prosedur penjualan tidak berjalan sesuai dengan yang diharapkan perusahaan. Oleh karena itu diperlukan suatu sistem penjualan yang baik dan tepat, sebab sistem informasi akuntansi yang kurang memadai dapat menyebabkan terjadinya kecurangan-kecurangan sehingga akan berdampak kerugian bagi perusahaan. Kom, dkk (2007) mengatakan bahwa "Suatu sistem adalah sekumpulan elemen yang saling terkait atau terpadu yang dimaksudkan untuk mencapai suatu tujuan."

George dan William (1996) mengemukakan bahwa "Suatu sistem adalah kumpulan sumberdaya yang berhubungan untuk mencapai tujuan tertentu."

Hall (2009) dalam bukunya mengemukakan "Suatu sistem adalah kelompok dari dua atau lebih komponen atau subsistem yang saling berhubungan yang berfungsi dengan tujuan yang sama."

Definisi sistem informasi menurut George dan William (1996) dalam bukunya "Sistem Informasi Akuntansi" adalah sebagai berikut: "Sistem Informasi "berbasis komputer" merupakan sekelompok perangkat keras dan perangkat lunak yang dirancang untuk mengubah data menjadi informasi yang bermanfaat." Sedangkan menurut James (2009) dalam bukunya "Sistem Informasi Akuntansi" adalah Sistem informasi merupakan serangkaian prosedur formal dimana data dikumpulkan, diproses menjadi informasi dan didistribusikan ke para pengguna."

Sistem informasi akuntansi adalah kumpulan sumberdaya, seperti manusia dan peralatan, yang diatur untuk mengubah data menjadi informasi, informasi ini dikomunikasikan kepada beragam pengambil keputusan. (George dan William 1996). Krismiaji (2010) mengemukakan bahwa: "Sistem informasi akuntansi adalah sebuah sistem yang memproses data dan transaksi guna menghasilkan informasi yang bermanfaat untuk merencanakan, mengendalikan dan mengoperasikan bisnis.

Lain halnya menurut James (2009), mendefinisikan "sistem informasi akuntansi merupakan kumpulan-kumpulan dari sub-sub sistem atau komponen baik fisik 
maupun non fisik yang saling berhubungan dan bekerja sama satu sama lain secara harmonis untuk mengolah data transaksi yang berkaitan dengan masalah keuangan menjadi informasi keuangan.

Sistem Informasi Akuntansi (SIA), sebagai suatu sistem tidak dapat berdiri sendiri, karena harus berhubungan dengan sistem-sistem informasi lain yang ada di dalam perusahaan. Suatu sistem biasanya memiliki subsistem-subsistem yang lebih kecil. Bila dilihat dari subsistem, sekumpulan subsistem akan memiliki sistem induk, atau disebut supra sistem. Wing Wahyu (2006: 1.15) berpendapat, bahwa setiap sistem informasi akuntansi di dalam suatu perusahaan memiliki hubungan dengan sistem yang lebih besar maupun lebih kecil.

Selanjutnya unsur-unsur sistem informasi akuntansi dapat dijelaskan sebagai berikut : 1) sumber daya manusia, sumber daya manusia merupakan potensi manusia atas peranannya atas pelaksanaan suatu sistem didalam suatu perusahaan. Sistem informasi akuntansi pada umumnya diberi nama menurut sumber daya manusia yang digunakan. Manusia merupakan unsur sistem informasi akuntansi yang berperan dalam pengambilan keputusan dan mengendalikan jalannya sistem informasi.

Alat

Alat merupakan metode semua sarana dan prasana yang digunakan dalam menjalankan pelaksanaan suatu sistem informasi akuntansi didalam suatu perusahaan. Alat merupakan unsur sistem informasi akuntansi yang berperan di dalam mempercepat pengolahan data menggunakan komputer, meningkatkan ketelitian kalkulasi atau perhitungan dan meningkatkan kerapian bentuk organisasi.

Metode; yang terdiri dari : a) organisasi merupakan wadah kerjasama antara dua orang atau lebih untuk mencapai tujuan bersama dalam koordinasi suatu bangunan sistem. Organisasi berarti penentu pengkelompokan dan pengaturan dari berbagai aktivitas yang dianggap perlu untuk mencapai tujuan. Struktur organisasi harus dilengkapi dengan uraian tugas (job description) yang mengatur tentang tugas, hak, dan wewenang masing-masing pejabat beserta seluruh jajarannya sesuai fungsinya.

b) prosedur merupakan suatu urutan dari suatu pekerjaan tata usaha yang biasa melibatkan beberapa petugas yang diadakan untuk menjamin pelaksanaan yang seragam dari transaksi yang berulang-ulang didalam perusahaan. Prosedur-prosedur yang termasuk dalam kegiatan persediaan bahan baku adalah prosedur pembelian persedian bahan baku, prosedur penerimaan persedian bahan baku, prosedur penyimpanan dan pengeluaran persediaan bahan baku, c) formulir merupakan alat bantu yang berupa daftar isian yang berfungsi sebagai alat bukti atas terjadi transaksi. Data juga dihasilkan dari formulir-formulir yang digunakan sebagai bukti tertulis dari transaksi, contoh: faktur penjualan barang, bukti pembayan dan lain-lain.

c) pencatatan merupakan pengumpulan dan pengkelompokan data, biasanya dicatat didalam suatu buku catatan untuk memudahkan proses pengolahan data selanjutnya. Data yang dihasilkan dari catatan-catatan berupa jurnal-jurnal buku besar, dan buku tambahan, d) Pelaporan merupakan keluaran dari suatu sistem pengolahan data yang melibatkan koordinasi manusia, alat dan metode didalam suatu 
perusahaan. Informasi tersebut antara lain dapat berupa neraca, laporan laba rugi, laporan perubahan modal, laporan arus kas, laporan laba ditahan, laporan harga pokok penjualan, daftar saldo persediaan, dan sebagainya.

\section{Sistem Informasi Penjualan} Kredit. Mulyadi (2001) menjelaskan sistem informasi akuntansi penjualan kredit yaitu penjualan dilaksanakan oleh perusahaan dengan cara mengirimkan barang sesuai dengan order yang diterima dari pembeli dan untuk jangka waktu tertentu perusahaan mempunyai tagihan kepada pembeli tersebut. Jadi dalam sistem informasi akuntansi penjualan terdapat unsur-unsur yang mendukung dan kesemua unsur tersebut diorganisasi sedemikian rupa dalam sebuah sistem informasi akuntansi yang disebut sistem informasi akuntansi penjualan.

Adapun fungsi-fungsi yang dalam sistem informasi akuntansi penjualan yang berkaitan dengan aktivitas penjualan sejak timbulnya pesanan penjualan sampai dengan penerimaan hasil penjualan menurut mulyadi (2001) adalah: Fungsi penjualan, Fungsi kredit, Fungsi gudang, Fungsi pengiriman barang, Fungsi pengiriman dan Fungsi kas

\section{METODE PENELITIAN}

Penelitian yang digunakan oleh peneliti adalah jenis penelitian deskriptif kualitatif. Penelitian deskriptif kualitatif adalah suatu penelitian yang menggambarkan subjek dan objek penelitian berdasarkan fakta yang ada dilapangan dan data-data yang diperoleh adalah kata-kata bukan angka. Penelitian deskriptif kualitatif ini adalah suatu metode dalam meneliti dimana pemecahan masalah yang diselidiki dengan menggambarkan atau melukiskan keadaan subjek atau objek penelitian.

Data yang dikumpulkan oleh peneliti dalam rangka memperoleh data yang diperlukan, maka peneliti menggunkanan dua sumber data yaitu : Data Primer dan Data sekunder.

Teknik Pengumpulan Data yang digunakan dalam penelitian ini yaitu: Teknik Dokumentasi, Teknik wawancara dan Teknik pengamatan/observasi.

Teknik analisis data yang digunakan untuk memecahkan permasalahan adalah dengan cara menganalisis data-data penelitian yaitu pengendalian yang tidak membutuhkan pembuktian dengan menggunakan angka-angka atau perhitungan, melainkan penganalisaan dalam bentuk uraian-uraian. Pembuktian dilakukan secara logis dan rasional melalui pendapat dan teori-teori yang diterima. Metode analisis data yang digunakan dalam penelitian ini adalah sebagai berikut : 1) mengungkapkan sistem informasi akuntansi bagian penjualan kredit pada PD. Sinar Mas Hakasima Cabang Jember melalui sistem dan prosedur yang ada dalam sistem informasi akuntansi penjualan kredit ,2) mengevaluasi unsur-unsur sistem informasi akuntansi yang ada pada PD. Sinar Mas Hakasima Cabang Jember, 3) membuat kesimpulan hasil penelitian yang telah dilakukan oleh peneliti pada PD. Sinar Mas Hakasima Cabang Jember, 4) memberikan saran mengenai rencana pelaksanaan penjualan kredit yang berhubungan dengan teori-teori mengenai sistem informasi akuntansi.

\section{HASIL DAN PEMBAHASAN}

\section{Sistem Informasi Akuntansi Penjualan Kredit}

Jaringan Prosedur yang membentuk sistem penjualan kredit 
pada PD. Sinar Mas Hakasima Cabang Jember :

1. Prosedur Order Penjualan. Dalam prosedur order penjualan ini, fungsi order processor penjualan menerima permintaan konsumen. Fungsi order processor penjualan kemudian membuat daftar pesanan barang dan mengirimkan kepada berbagai fungsi yang lainnya. Penjualan membuat faktur penjualan dan mengirimkan ke berbagai fungsi yang lain untuk memungkinkan fungsi-fungsi yang lain mengetahui harga barang dari pembeli. Selain itu sales order akan mendapatkan komisi apabila mencapai omset yang telah ditetapkan oleh perusahaan sebelumnya.

2. Prosedur Persetujuan Kredit. Dalam prosedur persetujuan kredit, bagian marketing meminta persetujuan penjualan kredit kepada pembeli tertentu. Bagi pembeli baru, order tersebut diterima setelah diotorisasi oleh kepala cabang, supervisor, sales dan konsumen, sedangkan bagi pembeli lama akan dilakukan pemeriksaan saldo piutang pembeli yang bersangkutan untuk mengetahui status kreditnya. Jika pembeli tersebut masih memiliki piutang yang belum dibayar maka pembeli tersebut belum bisa mendapatkan kredit lagi.

3. Prosedur Pengiriman. Dalam prosedur pengiriman ini, fungsi gudang memberikan barang sesuai dengan pesanan konsumen dan menyiapkan barang kemudian mengirimkan barang beserta faktur kepada pelanggan sesuai dengan informasi yang tercantum pada surat pengantar yang diterima dari fungsi kasir yang sudah di otorisasi oleh fungsi pengiriman.

4. Prosedur Penagihan. Dalam prosedur penagihan ini, bagian penagihan membuat faktur penjualan berdasarkan pesanan penjualan. Faktur penjualan ini di siapkan dan dikirim kepada konsumen setalah 2-6 hari paling lama konsumen menerima pesanan barang. Setelah pengiriman tagihan, selanjutnya pelanggan akan membicarakan cara pembayaran yang akan dilaksanakan baik itu secara tunai maupun kredit.

5. Prosedur Pencatatan piutang. Dalam prosedur ini, bagian fungsi akuntansi yang bertanggung jawab akan mencatat piutang pelanggan dalam laporan penjualan secara komputerisasi dan membuat surat penagihan sebagai rekapan dari piutang PD. Sinar Mas Hakasima Cabang Jember.

6. Prosedur Distribusi Penjualan. Dalam prosedur penjualan ini, fungsi akuntansi mencatat hasil transaksi penjualan kredit ke dalam jurnal penjualan. Dimana dari sales dan pelanggan akan melakukan kesepakatan membeli barang yang dibutuhkan oleh konsumen untuk kemudian disetorkan ke kasir untuk di konfirmasi kepada kepala kasir.

\section{Perbandingan antara Unsur-Unsur Sistem Informasi Akuntansi}

\section{Tabel 1}

\section{Perbandingan antara Unsur-Unsur} Sistem Informasi Akuntansi

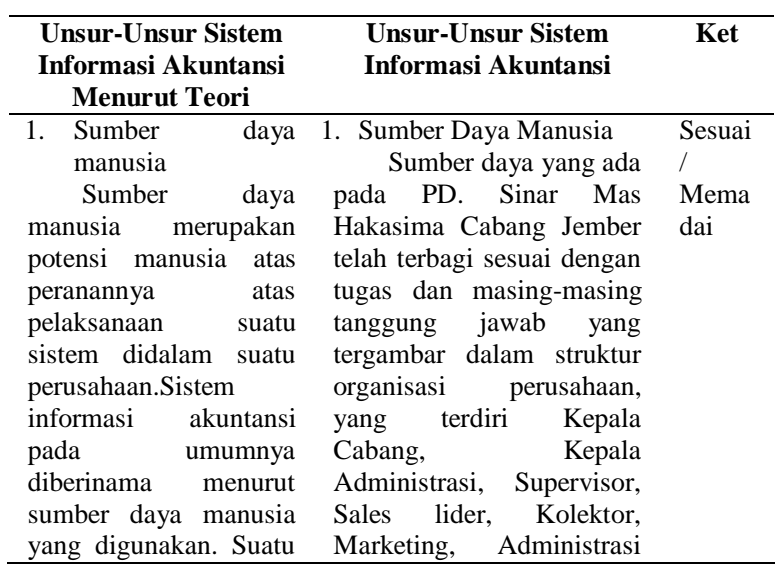




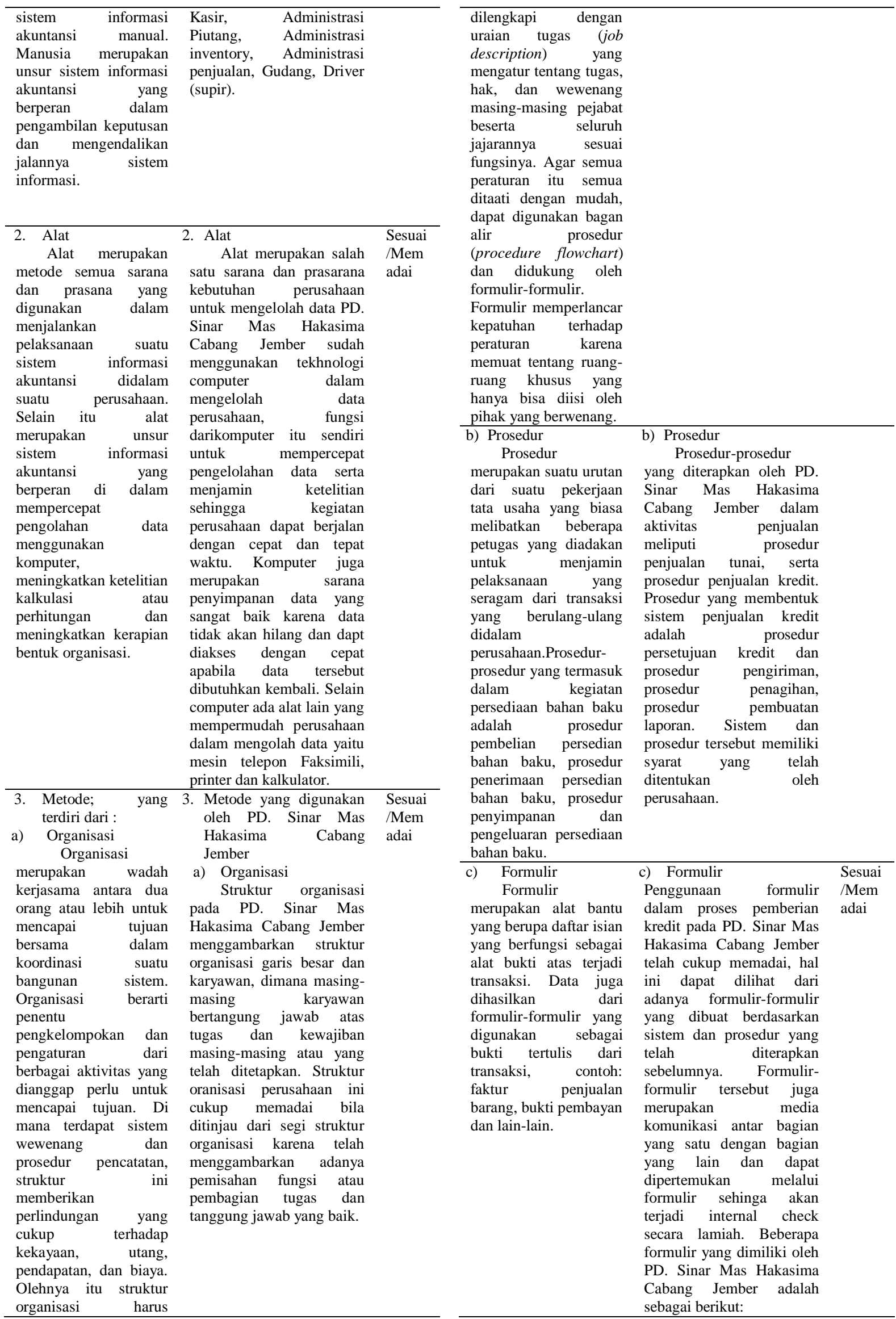




\begin{tabular}{|c|c|c|}
\hline & $\begin{aligned} & \text { i. } \text { Surat Jalan } \\
& \text { ii. } \text { Faktur / Delivery } \\
& \text { Order (DO) } \\
& \text { iii. } \text { Bukti pemindahan } \\
& \text { stock (BPS) } \\
&\end{aligned}$ & \\
\hline $\begin{array}{lr}\text { d) Pencatatan } \\
\text { Pencatatan merupakan } \\
\text { pengumpulan dan } \\
\text { pengkelompokan data, } \\
\text { biasanyar dicatat } \\
\text { didalam suatu } & \text { buku } \\
\text { catatan } & \text { untuk } \\
\text { memudahkan proses } \\
\text { pengolahan rata } \\
\text { selanjutnya. Data yang } \\
\text { dihasilkan dari catatan- } \\
\text { catatan berupa jurnal- } \\
\text { jurnal buku besar, dan } \\
\text { buku tambahan. }\end{array}$ & $\begin{array}{l}\text { d)Pencatatan } \\
\quad \text { PD. Sinar Mas } \\
\text { Hakasima Cabang Jember } \\
\text { memiliki beberapa catatan } \\
\text { berupa jurnal-jurnal } \\
\text { pemberian kredit, buku } \\
\text { besar yang diberikan, serta } \\
\text { buku besar pembantunya. } \\
\text { Jurnal dicacat setiap } \\
\text { terjadinya pemberian } \\
\text { kredit. Pencatatan } \\
\text { dilakukan oleh bagian } \\
\text { kasian dimulai dari } \\
\text { pembayaran angsuran } \\
\text { tagihan sampai dengan } \\
\text { menginput ke computer } \\
\text { untuk pelunasa kredit. } \\
\text { Selain itu, pencatatan juga } \\
\text { untuk mengetahui profil } \\
\text { cabang dan penjualan } \\
\text { cabang perbulan. }\end{array}$ & $\begin{array}{l}\text { Sesuai } \\
\text { /Mem } \\
\text { adai }\end{array}$ \\
\hline $\begin{array}{l}\text { e) Pelaporan } \\
\text { Pelaporan } \\
\text { merupakan keluaran } \\
\text { dari suatu sistem } \\
\text { pengolahan data yang } \\
\text { melibatkan koordinasi } \\
\text { manusia, alat dan } \\
\text { metode didalam suatu } \\
\text { perusahaan. Hasil akhir } \\
\text { dari sistem informasi } \\
\text { akuntansi adalah } \\
\text { informasi akuntansi } \\
\text { keuangan dan informasi } \\
\text { akuntansi manajemen. } \\
\text { Informasi tersebut } \\
\text { antara lain dapat berupa } \\
\text { neraca, laporan laba } \\
\text { rugi, laporan perubahan } \\
\text { modal, laporan arus } \\
\text { kas, laporan laba } \\
\text { ditahan, laporan harga } \\
\text { pokok penjualan, daftar } \\
\text { saldo persediaan, dan } \\
\text { sebagainya. }\end{array}$ & $\begin{array}{l}\text { e) Pelaporan } \\
\text { PD. Sinar Mas } \\
\text { Hakasima Cabang Jember } \\
\text { menghasilkan laporan- } \\
\text { laporan yang didapat dari } \\
\text { hasil pelaksanaan } \\
\text { pengolahan data berupa } \\
\text { laporan-laporan yang } \\
\text { diperuntukkan bagi pihak } \\
\text { intern dan ekstern. } \\
\text { Laporan tersebut dibuat } \\
\text { secara berkala, baik } \\
\text { laporan perbulan, Laporan } \\
\text { triwulan dan Laporan } \\
\text { tahunan. Laporan tersebut } \\
\text { terdiri dari tinjuauan } \\
\text { usaha, laporan jumlah } \\
\text { kredit yang diberikan, } \\
\text { laporan informasi yang } \\
\text { dihasilkan berupa laporan- } \\
\text { laporan yang diperoleh } \\
\text { dari hasil pengolahan data, } \\
\text { semua data yang diperoleh } \\
\text { perusahaan harus sesuai } \\
\text { dengan kebutuhan } \\
\text { manajemen agar dapat } \\
\text { menghasilkan informasi } \\
\text { laporan yang baik. Selain } \\
\text { itu pelaporan juga } \\
\text { berfungsi an untuk } \\
\text { mengetahui kegiatan daftar } \\
\text { hadir karyawan, } \\
\text { mengetahui penjualan, } \\
\text { mengetahui transaksi dan } \\
\text { kegiatan sales. }\end{array}$ & $\begin{array}{l}\text { Sesuai } \\
\text { /Mem } \\
\text { adai }\end{array}$ \\
\hline
\end{tabular}

\section{Evaluasi Terhadap Sistem Informasi} Akuntansi

1. Evaluasi Terhadap Prosedur Order Penjualan

Dalam prosedur order penjualan pada PD. Sinar Mas Hakasima Cabang
Jember, fungsi order penjualan menerima permintaan pelanggan. Fungsi order penjualan kemudian membuat daftar pesanan produk/barang dan mengirimkannya kepada berbagai fungsi yang lainnya. Penjualan membuat faktur penjualan dan mengirimkannya ke berbagai fungsi yang lain untuk memungkinkan fungsifungsi yang lain mengetahui harga barang dari pembeli. Selain itu sales order juga mendapatkan komisi dari setiap unit yang telah terjual. Atas dasar surat pesanan tersebut, maka bagian penjualan membuat surat order penjualan (OSR) sebanyak 6 lembar dan selanjutnya mendistribusikan kepada: a) lembar ke 1 dan order dari pelanggan diserahkan ke bagian penagihan untuk diarsipkan, b) lembar ke 2 diserhkan ke bagian pengiriman, c) lembar ke 3 dan ke 4 dikirimkan ke bagian kredit untuk dimintakan persetujuan, d) lembar ke 5 dan order penjualan dikirimkan ke pelanggan, e) lembar ke 6 dari order penjualan di arsipkan oleh bagian penjualan berdsarkan urut nomor

\section{Evaluasi Terhadap Prosedur Persetujuan Kredit \\ Prosedur persetujuan kredit pada} PD. Sinar Mas Hakasima Cabang Jember. Dalam prosedur ini, bagian marketing meminta persetujuan penjualan kredit kepada pembeli tertentu. Bagi pembeli baru, order tersebut diterima setelah diotorisasi oleh SPV dan sales marketing, sedangkan bagi pembeli lama akan dilakukan pemeriksaan saldo piutang pembeli yang bersangkutan untuk mengetahui status kreditnya. Jika pembeli tersebut masih memiliki piutang yang belum dibayar maka pembei tersebut belum bisa mendapatkan kredit lagi, atas dasar surat penjualan lembar ke 3 dan ke 4 yang dikirim oleh bagian penjualan, maka setelah surat order tersebut 
diterima maka bagian kredit melakukan pemeriksaan kredit pelanggan, yang mencakup sejarah kredit dan batas kredit pelanggan. Selanjutnya bagian ini memberikan persetujuan (tanda tangan) terhadap surat order penjualan tersebut dan meneruskan ke bagian gudang. Setelah itu dibagian gudang mempersiapkan barang yang akan dikirim serta mendistribusikan OSR kepada: a) lembar ke 3 bersama barang diserahkan ke bagian pengiriman, b) lembar ke 4 di arsipak berdasarkan nomer urut

\section{Evaluasi Terhadap Prosedur Pengiriman}

Dalam prosedur pengiriman pada PD. Sinar Mas Hakasima Cabang Jember, fungsi gudang memberikan barang sesuai dengan pesanan pelanggan dan menyiapkan barang kemudian mengirimkan barang beserta faktur kepada pelanggan sesuai dengan informasi yang tercantum pada surat pengantar yang diterima dari fungsi kasir yang sudah di otorisasi oleh fungsi pengiriman. Atas dasar kedua dokumen tersebut bagian pengiriman membuat nota pengiriman sebanyak 3 lembar dan mendistribusikan kepada: a) lembar ke 1 bersama-sama dengan surat order penjualan yang telah di otorisasi dan diserahkan ke bagian penagihan, b) lembar ke 2 bersama-sama dengan surat order penjualan lembar ke 2 diarsipkan menurut urut tanggal, c) lembar ke 3 bersama-sama dengan barang dikirimkan kepada pelanggan

\section{Evaluasi Terhadap Prosedur Penagihan \\ Dalam prosedur penagihan pada} PD. Sinar Mas Hakasima Cabang Jember, bagian penagihan membuat faktur penjualan berdasarkan pesanan penjualan. Faktur penjualan ini di siapkan dan dikirim kepada pelanggan setalah 2-6 hari paling lama pelanggan menerima pesanan barang. Setelah pengiriman tagihan, selanjutnya pelanggan akan membicarakan cara pembayaran yang akan dilaksanakan baik itu secara tunai maupun kredit. Atas dasar keempat dokumen ini bagian penagihan membuat faktur penjualan sebanyak 3 lembar kemdudian mendistribusikan kepada: a) lembar ke 1 dikirim kepada pelanggan, b) lembar ke 2 diserahkan ke bagian piutang, c) lembar ke 3 diarsipkan menurut urut nomor bersama-sama dengan surat order penjualan lembar ke 3 yang di otorisasi.

\section{Evaluasi Terhadap Prosedur Pencatatan piutang

Prosedur PD. Sinar Mas

Hakasima Cabang Jember, bagian fungsi akuntansi yang bertanggung jawab akan mecnatat piutang pelanggan dalam laporan penjualan secara komputerisasi dan membuat surat penagihan sebagai rekapan dari piutang PD. Sinar Mas Hakasima Cabang Jember. Fungsi akuntansi mencatat tembusan faktur penjualan kedalam kartu piutang dengan mengarsipkan dokumen tembusan menurut abjad yang berfungsi sebagai catatan piutang. Setelah menerima faktur penjualan lembar ke 2 dari bagian penagihan maka bagia piutang gudang mencatat dalam kartu harga pokok untuk barang yang telah dikirim.

\section{Evaluasi Terhadap Prosedur Distribusi Penjualan \\ Dalam prosedur penjualan pada} PD. Sinar Mas Hakasima Cabang Jember, fungsi akuntansi mencatat hasil transaksi penjualan kredit ke dalam jurnal penjualan. Dimana dari sales marketing dan pelangan akan melakukan kesepakatan membeli produk/barang yang dibutuhkan oleh 
pelanggan untuk kemudian disetorkan ke kasir untuk di konfirmasi kepada kepala kasir. Prosedur ini seharusnya bagian fungsi akuntansi mendistribusikan data penjualan yang diperlukan oleh manajemen atau pimpinan cabang untuk di konfirmasi bukan kasir yang memutuskan atas penjualan.

\section{Evaluasi Terhadap Unsur-Unsur Sistem Informasi Akuntansi}

\section{Sumber Daya Manusia}

Sumber daya manusia dalam sistem akuntansi adalah orang-orang yang mengoprasikan sistem tersebut dan melaksanakan berbagai fungsi baik dalam prosedur-prosedur baik yang manual maupun yang terkomputerisasi yang dilibatkan dalam mengumpulkan, memproses dan menyimpan data tentang aktifitas-aktifitas organisasi, data tentang proses bisnis perusahaan software yang dipakai untuk proses data perusahaan, dalam PD. Sinar Mas Hakasima Cabang Jember sudah tergambar dalam struktur organisasi perusahaan dan tugas-tugas dari masing-masing bagian.

\section{Terhadap alat}

Alat yang digunakan oleh PD. Sinar Mas Hakasima Cabang Jember sudah menggunakan tekhnologi computer dalam mengelolah data perusahaan dan infrastruktur tekhologi akuntasi termasuk computer. Telepon faksimili, printer, kalkulator dan komunikasi jaringan. Computer merupakan alat yang dipakai untuk mengelolah data menurut prosedur yang telah dirumuskan dan dapat mempercepat pengelolahan data serta menjamin ketelitian sehingga dapat berjalan dengan cepat dan tepat waktu.

\section{Metode}

Struktur organisasi. Struktur oranisasi menggambarkan dengan jelas pemisahan kegiatan pekerjaan antara satu dengan yang lainnya dan bagaimana aktifitas dan fungsi dibatasi. Dalam suatu organisasi yang baik harus menjelaskan hubungan wewenang siapa melapor kesiapa jadi ada suatu pertanggung jawaban atas apa yang dikerjakan.

Penyusunan suatu sistem tidak dapat lepas dari suatu organisasi untuk itu terlebih dahulu dilakukan penilaian apakah suatu organisasi yang ada telah memiliki integritas yang baik, memisahkan funsi-fungsi secara jelas, terdapat pembatasan yang jelas antara unit-unit yang ada, da nada pengenalian intern yang baik.

Pada PD. Sinar Mas Hakasima Cabang Jember struktur organisasi sudah cukup baik karena dapat dilihat dari divisi yang memiliki pemisahan fungsi serta tangung jawab yang berbeda.

\section{Terhadap prosedur}

Prosedur mengidentifikasikan rangkaian aktifitas, tugas-tugas langakah-langkah, keputusankeputusan, proses-proses, yang dijalankan melalui serangkaian pekerjaan yang menghasilkan suatu tujuan yang diinginkan dalam suatu urutan kegiatan. Prosedur-prosedur yang diterapkan oleh PD. Sinar Mas Hakasima Cabang Jember sesuai dengan aktifitas yang berurutan, prosedur untuk menyempurnakan penjualan kredit adalah prosedur penjualan kredit, prosedur persetujuan kredit, prosedur pengiriman, prosedur penagihan, prosedur pencatatan laporan. Prosedur-prosedur tersebut yang telah ditentukan oleh PD. Sinar Mas Hakasima Cabang Jember.

\section{Terhadap Formulir}


Dalam menjelaskan suatu kegiatan, aktifitas tidak terlepas dari formulir yang akan digunakan. Formulir yang digunakan haruslah mengandung unsur yangmendukung terhadap aktifitas penjualan kredit, penggunaan formulir pada PD. Sinar Mas Hakasima Cabang Jember cukup baik, dilihat dengan adanya formulir-formulir yang dibuat berdasarkan sistem dan prosedur yang telah ditetapkan; a) adanya unsur internal check dalam merancang formulir, b) adanya nama dan alamat pelanggan pada formulir yang dapat digunakan untuk komunikasi, c) adanya nomer urut tercetak, d) nama Formulir yang memudahkan identifikasi. Selain itu untuk setiap formulir yang digunakan dalam tiap transaksi langsung di entry ke dalam computer.

\section{Terhadap Pencatatan}

Pada bagian pencatatan pada PD. Sinar Mas Hakasima Cabang Jember memiliki beberapa catatan. Dan data yang dihasilkan dari catatan-catatan, mulai dari proses mengumpulkan data dari faktur-faktur atas suatu ransaksi yang telah disetujui perusahaan dan disusun dalam jurnal umum, memindah atau posting dari jurnal umum ke dalam buku besar dan buku pembantu, jurnal dicatat setiap terjadinya penjualan kredit. Pencatatan dilakukan oleh bagian kasir, catatan akuntansi yang digunakan PD. Sinar Mas Hakasima Cabang Jember untuk mengetahui hasil penjualan perbulan.

\section{Pelaporan}

Penyusunan laporan keuangan pada PD. Sinar Mas Hakasima Cabang Jember mengahasilkan laporan-laporan dari hasil pengolahan data. Laporanlaporan merupakan proses yang penuh perimbangan dalam ranka membantu mengevaluasi posisi keuangan dan hasil operasi perusahaan pada masa sekarang dan masalalu, dengan tujuan untuk menentukan estimasi dan prediksi yang paling mungkin mengenai kondisi dan kinerja perusahaan dimasa mendtang. PD. Sinar Mas Hakasima Cabang Jember menghasilkan laporan-laporan yang di dapat dari hasil pengolahan data. Pelaporan dalam PD. Sinar Mas Hakasima Cabang Jember berfungsi untuk mengetahui kinerja perusahaan, pemdapatan, dan penghasilan yang memadai.

\section{PENUTUP \\ Kesimpulan}

Dari hasil analisis yang dialkukan pada PD. Sinar Mas Hakasima Cabang Jember dapat ditarik kesimpulan adalah sebagai berikut:

1. Sistem informasi penjualan kredit pada PD. Sinar Mas Hakasima Cabang Jember pada prosedur order penjualan, prosedur persetujuan kredit, prosedur pengiriman, prosedur penagihan, prosedur pencatatan piutang dan yang terakhir prosedur distribusi penjualan, sudah memenuhi prosdur penjualan kredit.

2. Unsur-unsur sistem informasi akuntansi pada PD. Sinar Mas Hakasima Cabang Jember sudah memenuhi prosedur-prosedur dari unsur-unsur sistem informasi akuntansi yang sudah dikemukakan diantaranya dari sumber daya manusia, alat, metode yaitu organisasi, prosedur, formulir, dan pencatatan, dan yang terakhir adalah segi pelaporan.

\section{Saran}

Bagi pihak-pihak lain yang tertarik meneliti topik ini, maka peneliti menyarankan untuk memilih objek penelitian yang lain, bisa pada perusahaan industri maupun perusahaan manufaktur yang cakupannya lebih luas. 
Jadi tidak terfokus pada perusahaan dagang saja.

\section{DAFTAR PUSTAKA}

Azhar, S. (2008). Sistem Informasi Akuntansi . Bandung: Lingga Jaya.

George H. \& William S. (1996). Sistem Informasi Akuntansi. Buku Satu, Terjemahan Amir Abadi Jusuf. Jakarta: Salemba Empat,

Hall, J., A. (2009). Sistem Informasi Akuntansi. Edisi Empat. Jakarta: Salemba Empat.

Kom, K., M. \& Koniyo. A. (2007). Tuntunan Praktis Sistem Informasi Akuntansi Dengan Visual Basic Dan Microsoft SQL Server.

Krismiaji. (2010). Sistem Informasi Akuntansi . Edisi Ketiga. Yogyakarta: Sekolah Tinggi Ilmu Manajemen.

Widjajanto, N. (2001). Sistem Informasi Akuntansi. Jakarta: Erlangga 